\title{
ESTRATÉGIAS \\ CONVERSACIONAIS \\ EMPREGADAS POR \\ JAIR BOLSONARO \\ NO INÍCIO DA \\ PANDEMIA \\ DE COVID-19
}

\section{ESTRATEGIAS CONVERSACIONALES UTILIZADAS POR JAIR BOLSONARO AL INICIO DE LA PANDEMIA COVID-19}

CONVERSATIONAL STRATEGIES EMPLOYED BY JAIR BOLSONARO AT THE BEGINNING OF THE COVID-19 PANDEMIC

Elaine de Castro*

Vanessa Hagemeyer Burgo**

Universidade Federal do Mato Grosso do Sul

RESUMO: O objetivo deste trabalho é analisar as estratégias empregadas pelo presidente Jair Bolsonaro em suas declarações a respeito da pandemia de Covid-19 durante os meses de março e abril de 2020. O corpus é formado por excertos retirados de entrevistas, pronunciamentos e lives, selecionados e publicados em primeiro de maio do mesmo ano na seção de saúde pelo website UOL Notícias. Pautado na Análise da Conversação, este estudo traz os conceitos de face, polidez, bem como marcadores conversacionais utilizados como formas de distanciamento e de envolvimento do falante em relação ao tópico discursivo. São analisadas, portanto, nove falas do político visando a verificar os mecanismos utilizados por ele no intuito de opinar e preservar sua autoimagem pública entre seus ouvintes. De acordo com os resultados, o emprego desses recursos contribuiu para uma postura de incredulidade do falante acerca das estatísticas e orientações de órgãos de saúde nacionais e internacionais.

PALAVRAS-CHAVE: Análise da Conversação. Face. Polidez. Marcadores Conversacionais. Pandemia.

RESUMEN: El objetivo de este trabajo es analizar las estrategias empleadas por el presidente Jair Bolsonaro en sus declaraciones sobre la pandemia del covid-19 durante los meses de marzo y abril de 2020. El corpus está formado por extractos extraídos de

\footnotetext{
* Doutoranda em Letras na Universidade Federal do Mato Grosso do Sul. É professora de Língua Inglesa na Educaça Básica ensino Superior. E-mail: elainec.teacher@gmail.com.

** Possui pós-doutorado em Inglês: Estudos Linguísticos e Literários pela UfSC, doutorado e mestrado em Estudos da Linguagem pela UEL. É professora do Curso de Letras e do Programa de Pós-Graduação em Letras da UFMS. E-mail: vanessahburgo@hotmail.com
} 
entrevistas, discursos y lives, seleccionados y publicados el 1 de mayo del mismo año en la sección de salud del sitio web UOL Notícias. Basado en el Análisis de la Conversación, este estudio aporta los conceptos de imagen, cortesía, así como los marcadores conversacionales utilizados como formas de distanciamiento e implicación del hablante en relación con el tema discursivo. Por lo tanto, se analizan nueve discursos del político para comprobar los mecanismos que utiliza para dar su opinión y preservar su autoimagen pública entre sus oyentes. Según los resultados, el uso de estos recursos contribuyó a una postura de incredulidad del orador sobre las estadísticas y directrices de los organismos sanitarios nacionales e internacionales.

PALABRAS CLAVE: Análisis de Conversación. Imagen. Cortesía. Marcadores conversacionales. Pandemia.

ABSTRACT: This study aims to analyze the strategies that President Jair Bolsonaro employed in his statements about the Covid19 pandemic during the months of March and April 2020. The corpus is composed of interviews, speeches and lives, which were selected and published on May 1st of the same year in the health section of the Brazilian website UOL Notícias. Based on Conversation Analysis, this study brings the concepts of face and facework, politeness, as well as conversational markers used as forms of distance and involvement of the speaker in relation to the discursive topic. Therefore, nine statements of the politician are analyzed in order to verify the strategies used by him to express an opinion and preserve his public self-image among his listeners. According to the findings, the use of those devices contributed to the speaker's attitude of disbelief towards statistics and guidelines from national and international health agencies.

KEYWORDS: Conversation Analysis. Face and Facework. Politeness. Conversational Markers. Pandemic.

\section{INTRODUÇÃO}

O ano de 2020 foi marcado por um problema de ordem mundial: a pandemia do novo coronavírus. A doença é causada pelo vírus SARS-CoV-2 e transmitida de pessoa a pessoa, sendo o uso de máscaras de proteção e o isolamento social suas principais medidas preventivas. Identificado primeiramente em dezembro de 2019, em Wuhan na China, o vírus acometeu o Brasil no início de 2020, chegando ao mês de dezembro com praticamente 6,5 milhões de casos contabilizados (GOOGLE NOTÍCIAS, 2020)².

Este fato se tornou assunto recorrente no meio jornalístico e frequentemente divulgado pela mídia, tanto para a conscientização da população acerca das medidas de prevenção e controle da doença a partir de orientações de órgãos competentes, como a Organização Mundial de Saúde (doravante OMS), o Ministério da Saúde e instâncias estaduais e municipais do governo, quanto em debates e entrevistas com autoridades, visando a compreender, discutir e solucionar os problemas acarretados pela pandemia.

Nesse âmbito, o presidente brasileiro Jair Bolsonaro tem sido entrevistado a respeito deste assunto desde o início das medidas preventivas da doença e se tornou alvo de críticas por adotar atitudes e comportamentos contrários às orientações dos órgãos de saúde e demonstrar uma postura despreocupada mediante a gravidade representada pela pandemia.

Com o objetivo de analisar as escolhas linguísticas de Jair Bolsonaro a respeito do tópico discursivo exposto, a análise desenvolvida neste estudo, pautada nos pressupostos da Análise da Conversação (doravante AC), toma como base nove trechos de falas do presidente brasileiro em entrevistas, coletivas com repórteres, lives e pronunciamentos no início da pandemia, entre março e abril de 2020, retiradas de entrevistas, lives e pronunciamentos públicos, selecionados e publicados em 1 de maio do mesmo ano na seção de saúde do website UOL Notícias. Com o enfoque no par entrevistado-audiência, busca-se verificar estratégias e recursos conversacionais empregados pelo político ao emitir seu posicionamento e tomar atitudes com relação ao tópico discursivo da pandemia e seus desdobramentos, sobretudo no contexto midiático nacional.

Para tanto, este trabalho traz uma breve introdução sobre a AC (LEVINSON, 1983; MARCUSCHI, 1991; FÁVERO; ANDRADE; AQUINO, 2000), seguindo com os conceitos de face, estratégias de polidez e apresentando alguns marcadores conversacionais relevantes ao processo de análise (GOFFMAN, 1970; BROWN e YULE, 1983; BROWN e LEVINSON, 1987; MARCUSCHI, 1989; GALEMBECK, 1997, 1999; KERBRAT-ORECCHIONI, 2006; GUIMARÃES; 2010; SILVA, 2011; LINS; MARCHEZI,

${ }^{1}$ Dados de 03 de dezembro de 2020, com base nas informações diárias apresentadas no Google Notícias. 
2012; BURGO; STORTO; GALEMBECK, 2013). Em seguida, aspectos da entrevista jornalística são pontuados (FÁVERO, 2000) e a análise do material publicado online é apresentada, contando com a contextualização das falas do presidente e alguns pontos da AC encontrados nos excertos. Por fim, são tecidas algumas considerações a respeito dos recursos e estratégias observados.

\section{A ANÁLISE DA CONVERSAÇÃO}

Em busca de descrever estruturas e mecanismos organizadores da conversação, a AC iniciou-se na década de 60 tendo como princípios norteadores os aspectos de ação e interação social na organização, convencionalização e institucionalização da conversação. Metodologicamente, a AC parte da indução de dados empíricos reais, uma vez que não considera modelos préestabelecidos de conversação, como filmes, peças ou obras literárias, e, portanto, os estudos desenvolvidos nesta área consistem em descrições e interpretações qualitativas (MARCUSCHI, 1991).

Vinculada à situacionalidade, a AC considera o caráter pragmático da conversação:

Em outros termos, a vinculação contextual da ação e interação social faz com que toda atividade de fala seja vista ligada à realização local, mas de uma forma complexa, uma vez que a contextualidade é reflexiva e o contexto de agora é, em princípio, o emulador do contexto seguinte. Nesse processo são os próprios interlocutores que fornecem ao analista as evidências das atividades por eles desenvolvidas. (MARCUSCHI, 1991, p. 8)

Para Levinson (1983), a conversação é o gênero básico da interação humana, o que reforça o caráter dialógico da linguagem e a configura como uma interação verbal. A esse respeito, Marcuschi (1991, p.15) apresenta como características básicas desse processo a interação entre dois ou mais falantes, com ao menos uma troca de falantes, uma sequência de ações coordenadas, identidade temporal e envolvimento destes falantes numa 'interação centrada'.

Nesse sentido, o autor evidencia duas modalidades de diálogo: os assimétricos, como as entrevistas, aulas e inquéritos, nos quais um dos participantes orienta a interação e exerce pressão nos demais falantes, e os simétricos, mais relacionados à conversação diária, nos quais os falantes se encontram num mesmo nível com relação ao direito de interagir. Assim, é possível perceber que os textos conversacionais são coletivamente construídos e operam de forma organizada sem, no entanto, seguirem um modelo préestabelecido.

Por esse viés, Burgo, Storto e Galembeck (2013, p. 294) afirmam que, apesar de existirem diferenças e semelhanças na fala e na escrita, estas se encontram em um continuum tipológico da produção textual, marcado por gradações na tipificação textual, como o grau de formalidade ou a própria pressão no ambiente físico onde ocorre a comunicação, causando "[...] efeito sobre o material linguístico, isto é, sobre a organização da informação”.

Mais especificamente acerca do texto falado, Fávero, Andrade e Aquino (2000, p. 21) enfatizam que:

Dado o caráter de imprevisibilidade em relação aos elementos estruturais, o texto falado deixa entrever plenamente seu processo de organização, tornando-se possível perceber sua estrutura, bem como suas estratégias organizacionais. Dessa forma, observam-se nessa modalidade de texto muitos cortes, interrupções, retomadas, sobreposições, etc., de onde se deduz que, se o sistema da língua é o mesmo, tanto para fala quanto para a escrita, as relações sintáticas são de outra ordem.

As autoras ainda apontam quatro elementos básicos do texto conversacional: turno, tópico, marcadores conversacionais e pares adjacentes. Um turno consiste na produção do falante enquanto está com a palavra, caracterizando a conversação como uma sucessão de turnos. Um tópico discursivo consiste naquilo sobre o que se está falando. Os marcadores conversacionais envolvem elementos verbais, prosódicos (como entonação, voz, ritmo) e não-linguísticos (como olhar, riso, gesticulação). Por fim, os pares adjacentes são os pares de ação e reação na conversação, como pergunta-resposta, convite-aceitação, saudação-saudação, entre outros. 
A partir desses elementos, o texto falado é estruturado em nível local e global. No primeiro nível, é estruturado de acordo com os turnos, ou seja, a partir da produção do falante quando está com a palavra e seus pares, enquanto no nível global opera sob normas de organização de condução do tópico discursivo. Dessa forma, a AC não emprega as mesmas unidades sintáticas da língua escrita, mas toma como base princípios comunicativos em sua demarcação, por meio de marcadores com funções igualmente sintáticas e conversacionais.

Marcuschi (1991) divide essas unidades comunicativas em verbais, não verbais e suprassegmentais. Ao desconsiderar a conversação como um enfileiramento aleatório e sucessivo de turnos de modo unilateral, o autor enfatiza a concepção de um processo global de funcionamento cooperativo, cujo processo inferencial está diretamente relacionado à compreensão. O pesquisador observa que:

[...] a compreensão não é fruto do trabalho de um dos interlocutores apenas, e sim dinamicamente construída por vários, ao se considerar a bilateralidade dos atos conversacionais, que não podem ser vistos exclusivamente do ponto de vista de quem os produz ou de quem os recebe. Por isso mesmo é na forma de os interlocutores interagirem que reside a melhor fonte para a análise do processo de compreensão. Isto desencadeia um movimento em que o processo se torna co-inferencial. (MARCUSCHI, 1991, p. 84)

Mediante tais pressupostos da AC, a análise aqui desenvolvida trata de unidades comunicativas, tanto de ordem sintática quanto conversacional, e leva em consideração a interação de seus interlocutores em eventos comunicativos da esfera jornalística em âmbito nacional e internacional. Esses eventos foram, majoritariamente, realizados por meio da interação do presidente com repórteres em entrevistas de rádio, programas de televisão, coletivas de imprensa e pronunciamentos públicos e em lives, todos eles veiculados pela mídia e de livre acesso ao público, também interlocutores de suas falas.

Nesse sentido, alguns conceitos compreendidos pela AC serão abordados para fins de análise, com a intenção de abarcar aspectos do ato conversacional como um todo, a saber: a questão da face, os marcadores conversacionais e o evento interacional em que recursos de distanciamento e envolvimento do presidente da república enquanto locutor mediante ao tópico discursivo da pandemia de Covid-19 em sua chegada no país.

\section{A QUESTÃO DA FACE}

Goffman (1970) define face como a expressão social do indivíduo, a qual depende de processos de neutralização de ameaças à preservação desta imagem social. De acordo com Galembeck (1999), o conceito de face está relacionado com a interação face-aface da conversação, processo que ameaça a autoimagem pública dos participantes envolvidos no ato conversacional.

Corroborando a noção de Goffman, Brown e Levinson (1987) distinguem a face em positiva e negativa. No caso da autoimagem positiva, numa visão externa do 'eu', há a necessidade de aceitação do indivíduo pela sociedade, exibida em busca de aprovação ou reconhecimento. Já na face negativa, a visão interna do 'eu’, há o desejo de atuação livre da opinião social em prol da preservação da autoimagem.

Nesse ponto, Lins e Marchezi (2012) ressaltam que a face é algo construído coletivamente entre indivíduos, uma vez que:

[...] não se restringe ao interior ou à superfície do corpo de uma pessoa, mas é algo que se localiza nos eventos que acontecem em um encontro e é manifestada somente quando estes eventos são interpretados. Desse modo, é impossível ter total controle da própria face, já que não se consegue controlar a interpretação que o outro fará do que é dito. Pode-se afirmar, portanto, que a face é algo que está fora do controle do indivíduo, pois ela é, efetivamente, construída no outro. (LINS; MARCHEZI, 2012, p. 554-555)

Castro \& Burgo | Estratégias conversacionais empregadas por Jair Bolsonaro.. 
Considerando-se a imprevisibilidade da fala, a manutenção, a preservação e a salvação da face se tornam relevantes em variadas situações interacionais, as quais exigem dos interlocutores a recorrência a mecanismos de resguardo (GALEMBECK, 1999). De acordo com Silva (2011), situações face-a-face tendem a ameaçar a autoimagem dos participantes, sobretudo no caso de confrontos de ideias e posições. Segundo Kerbrat-Orecchioni (2006, p. 79), há atos que ameaçam tanto o locutor quanto o destinatário em suas faces positivas e negativas:

\footnotetext{
- atos que ameaçam a face negativa do emissor: é, por exemplo, o caso da oferta ou da promessa, pelas quais se propõe ou se compromete a efetuar um ato suscetível de lesar seu próprio território, num futuro próximo ou distante;

- atos que ameaçam a face positiva do emissor: a confissão, a desculpa, a autocrítica ou outros comportamentos "autodegradantes";

- atos que ameaçam a face negativa do receptor: as violações territoriais de natureza não-verbal são numerosas (ofensas proxêmicas, contatos corporais inadequados, agressões visuais sonoras ou olfativas, infiltração por invasão nas "reservas" do outro etc). Mas as ameaças territoriais também podem ser de natureza verbal: é isso que ocorre nas chamadas perguntas "indiscretas"; e no conjunto dos atos que são, em alguma medida, inoportunos ou "diretivos", como a ordem, a interpelação, a proibição ou conselho;

- atos que ameaçam a face positiva do receptor: são todos aqueles que colocam em risco o narcisismo do outro, como a crítica, a refutação, a reprovação, o insulto e a injúria, a chacota e o sarcasmo [...]
}

Nesse sentido, segundo Brown e Levinson (1987), as ameaças ocorrem por meio de negociações e dependem da ação do interlocutor, de modo aberto ou fechado. Atos ameaçadores abertos consistem em ameaças intencionais com ou sem atenuantes. A ausência de atenuantes representa uma forma mais direta e sem temer a reação do ouvinte, enquanto ao atuar com atenuantes, o interlocutor busca não prejudicá-lo, por meio de estratégias de polidez positiva ou negativa.

No caso deste estudo, ao analisarmos as falas de Jair Bolsonaro a seguir, as situações comunicativas envolvem a presença de um interlocutor direto, no caso o repórter, e de interlocutores indiretos, ou seja, seus ouvintes de modo geral. Dessa forma, a presença de atenuantes marca o distanciamento físico e hierárquico entre os interlocutores e permite ao locutor a adoção de estratégias que enfatizam sua postura mediante o tópico conversacional em foco: a pandemia.

As estratégias de polidez positiva demonstram o respeito e admiração do interlocutor pelo seu ouvinte, no intuito de manter sua face positiva. Guimarães (2010, p. 32) afirma que: "Ao usar de estratégias de polidez positiva, o falante indica que pertence ao mesmo grupo social do ouvinte, demonstra também alguma admiração pelo seu interlocutor e, ainda, que está disposto a beneficiar o ouvinte com sua cooperação na atividade interacional. Ao utilizar as estratégias de polidez positiva, o falante assume estratégias de envolvimento para diminuir a distância social".

As estratégias de polidez negativa, por sua vez, remetem à face negativa do ouvinte e atuam no intuito de escapar da imposição do interlocutor. Assim, o falante evita tópicos que possam invadir o território do ouvinte e emprega recursos suavizadores para expressar atos menos coercitivos do que orações mais diretas (KERBRAT-ORECCHIONI, 2006). Ainda, há a polidez indireta, uma estratégia fechada, na qual o falante realiza uma ameaça, mas sem a intenção de se comprometer, utilizando-a de forma discursiva não clara, a qual caberá à interpretação do ouvinte.

Mediante as estratégias de polidez, o falante lança mão das que julga serem mais convenientes à situação comunicativa, levando em conta seus interesses e propósitos perante seu interlocutor. Desse modo, a partir da estratégia adotada, o falante a materializa por meio de elementos linguísticos no texto conversacional, como será observado mais adiante nas falas de Bolsonaro acerca da banalização da pandemia. Assim, é importante ressaltar que a preservação da face está diretamente relacionada aos atos ameaçadores e, portanto, a escolha de estratégias acaba por levar em consideração a imagem do locutor em foco e o risco que tais atos representam a ela, enquanto presidente e figura pública. 
Aliados à preservação da imagem, os marcadores conversacionais representam recursos sintáticos e semânticos que operam na preservação ou não da face do locutor. A seguir, são apresentados alguns desses recursos e suas funções em meio à expressão do falante.

\section{OS MARCADORES CONVERSACIONAIS}

Além das estratégias de polidez evidenciadas no texto conversacional, os marcadores conversacionais (doravante MCs) são definidos por Burgo, Storto e Galembeck (2013, p. 297) como: “[...] elementos independentes sintaticamente do verbo, formados por um ou mais itens ou expressões lexicais, que corroboram o monitoramento da conversação e a organização do texto. Podem ser considerados semanticamente vazios, porém são extremamente relevantes na manutenção da interação”.

Nessa ordem, os MCs consistem em estruturas variadas, as quais evidenciam aspectos semânticos, pragmáticos, interacionais e textuais por meio de expressões utilizadas pelos falantes. De acordo com Marcuschi (1989), essas estruturas se subdividem em quatro grupos: 1) MCs simples, realizados por meio de um único lexema (verbos, advérbios, pronomes, conjunções etc.); 2) MCs compostos, os quais operam no conteúdo; 3) MCs oracionais, os quais variam em tempo e modo (assertivo, indagativo e exclamativo); e 4) MCs prosódicos, evidenciados por meio de recursos como contexto, voz e entonação.

Por esse viés, os MCs marcam as relações interacionais e o envolvimento dos interlocutores na conversação, de modo a articular aspectos contextuais individuais e partilhados entre os interlocutores, bem como as estruturas linguísticas utilizadas neste processo. Assim, os MCs ocupam diferentes posições e possuem caráter multifuncional na expressão dos falantes (BURGO, STORTO e GALEMBECK, 2013).

Quanto ao uso de marcadores e a preservação de face, Galembeck (1999) observa que os falantes assumem atitudes variadas de defesa e resguardo, sobretudo no que tange à manifestação de opiniões. Ao demonstrarem atitudes de distanciamento e envolvimento no texto conversacional, os falantes constroem o diálogo por meio de recursos variados, os quais foram sintetizados no Quadro 1.

Quadro 1: Marcadores e recursos de distanciamento e envolvimento do locutor na preservação de face com base no estudo de Galembeck (1999, p. 175-193)

\section{Marcadores e recursos que expressam o distanciamento do locutor}

\author{
Impessoalidade e indeterminação do \\ sujeito
}

Marcadores de rejeição
Apagamento de marcas da enunciação por meio de recursos gramaticais que expressam: impessoalidade (é possível que, parece que, é provável) e indeterminação do sujeito (dizem, falam, diz-se)

Antecipação do locutor para limitar ou neutralizar possíveis reações desfavoráveis, contrárias ou prejudiciais do interlocutor (que eu saiba, não sei, se não me engano).

\section{Marcadores e recursos que expressam o envolvimento do locutor}

\begin{tabular}{|c|c|}
\hline Marcadores de opinião & $\begin{array}{l}\text { Indicação de opinião própria do locutor, representada por verbos de opinião } \\
\text { em primeira pessoa do singular (acho, creio, suponho, vejo, noto) e certas } \\
\text { expressões adverbiais (na minha opinião, no que me diz respeito). }\end{array}$ \\
\hline Marcadores hedges & $\begin{array}{l}\text { Modificação do valor ilocutório de um enunciado, por meio de atenuadores, os } \\
\text { quais podem modificar a força assertiva dos enunciados (assim, quer dizer, } \\
\text { digamos, vamos dizer) e exprimir incerteza (talvez, quem sabe, sei lá, não sei). }\end{array}$ \\
\hline
\end{tabular}


Alusão a terceiros

Paráfrases
Incorporação de palavras de pessoas citadas, para maior fidedignidade ou valor de verdade, empregadas para obtenção de crédito ou aprovação.

Relação de equivalência semântica entre dois enunciados, empregada para reiterar ou reforçar pontos de vista ou conceitos pré-expostos.

Fonte: as autoras

Partindo desses recursos, o falante, na posição de locutor, evidencia em suas escolhas, além das estratégias de polidez, a preservação da autoimagem por meio de estruturas linguísticas que o distanciam ou aproximam do tópico conversacional, de seu público e da imagem de figura pública que lhe confere a identidade no contexto em que se insere. Portanto, o processo de escolha é um ato intencional e sua análise qualitativa, como propõe a AC, permite elucidar manifestações de opinião e posicionamentos via texto conversacional.

Levando-se em consideração as nove manifestações públicas do presidente a serem analisadas a partir dos referenciais teóricos aqui apontados, é possível assinalar que, ao abordar o problema mundial de Covid-19, o político sustenta uma postura de modo intencional, na qual faz escolhas de estruturas linguísticas e estratégias conversacionais, visando a manter sua autoimagem positiva diante dos ouvintes.

Dessa forma, anteriormente à análise de tais aspectos inerentes às falas de Bolsonaro, buscamos enfatizar também as relações estabelecidas frente ao evento interacional sob o tópico discursivo da pandemia. Para tanto, tratamos da (as)simetria do diálogo, visitando os pares representados pelas modalidades de entrevista jornalística a serem analisadas, bem como as questões de turno inerentes a estes trechos.

\section{OS PARES INTERACIONAIS}

Ao pensar a situação interacional na qual os trechos analisados neste trabalho acontecem, é possível associar os variados gêneros selecionados, dentre eles entrevistas, coletivas com repórteres, pronunciamentos e lives, à esfera jornalística. Mesmo com as suas diferenças quanto às interações de seus interlocutores, há aspectos convergentes em todos eles. Primeiramente, podemos considerar o contexto situacional específico de comunicação. Para Rodrigues (1997, p. 18): "[...] todo evento de fala acontece num contexto situacional específico, aqui entendido como o ambiente extralingüístico: a situação imediata, o momento e as circunstâncias em que tal evento acontece, envolvendo, inclusive, os próprios participantes com suas características individuais e possíveis laços que os unam".

Aliado a esse ambiente, o tópico discursivo é outro aspecto que permeia os gêneros discursivos nos quais as falas do presidente se inserem. Para Brown e Yule (1983, p. 73), o tópico pode ser considerado como aquilo acerca do que se fala ou se escreve. Está ligado ao conteúdo da interação, o qual depende do processo colaborativo entre os participantes, bem como da construção do sentido, que por sua vez, depende de uma "[...] série de fatores contextuais como: conhecimento de mundo, conhecimento partilhado, circunstâncias em que ocorre a conversação, pressuposições, etc” (FÁVERO, 1997, p. 38).

Nesse sentido, embora a autora pontue que em alguns casos a identificação do tópico discursivo não é clara, na seleção das falas de Bolsonaro consideradas como corpus de análise deste estudo, houve a busca pelo tópico discursivo da pandemia de Covid-19 como conteúdo central dos processos interacionais desenvolvidos. Em relação ao tópico, Fávero (1997, p. 39) define o papel dos participantes enquanto ouvintes e falantes:

[...] o falante precisa garantir a atenção do ouvinte, articulando bem sua fala e construindo seus enunciados de modo tal que o ouvinte identifique os elementos do tópico e estabeleça relações que colaborem na instauração do mesmo. O ouvinte, por sua vez, precisa prestar atenção no que o falante diz, descodificar os elementos (objetos, idéias, indivíduos, etc.) que têm função no desenvolvimento do tópico e identilicar as relações que se dão entre os referentes do mesmo. 
Dadas essas funções, no caso da entrevista jornalística, há o propósito de troca de informações entre entrevistador e entrevistado, por meio da coleta de fatos. De acordo com Fávero (2000, p. 68), ela é em instrumento de inter-relação humana, no qual "[...] busca-se uma interpenetração informativa que visa a quebrar isolamentos sociais, grupais, individuais", que pode permitir a "pluralização de vozes e à distribuição democrática da informação".

A autora estabelece, então, três pares de diálogo nessa atividade: entrevistador-entrevistado, entrevistado-audiência e entrevistador-audiência. Assim, cabe ao primeiro par informar e convencer o público, numa relação de cumplicidade e oposição. Quanto à audiência, esta é constituída de maneira genérica a compor expectativas para o evento da entrevista, o qual tende ao contrato ou à polêmica. A esse respeito, a autora distingue os dois polos da seguinte maneira: "No primeiro caso, os interlocutores buscam causar boa impressão na audiência, para isso tentam respeitar a fala do outro, costumam ceder o turno, evitam traços que demonstrem agressividade. Já no estilo polêmico, a interação pode apresentar inclusive a desqualificação de um dos interlocutores" (FÁVERO, 2000, p. 69).

Apesar das divergências, em ambos os tipos de entrevista, o par entrevistador-entrevistado busca interagir com a audiência. Portanto, ao analisar este gênero discursivo, é necessário levar em conta o processo interacional como um todo: a situação, as características dos participantes e as estratégias utilizadas por eles na construção conjunta do texto. Assim, Fávero (2000, p. 70) enfatiza o fato de que esse processo de interação caracteriza uma "certa disputa, na medida em que os interlocutores fazem parte de um jogo de linguagem que se instaura através de um processo de negociações, trocas, normas partilhadas, concessões”.

Há uma assimetria nas funções dos interlocutores, sobretudo no que tange aos seus papéis sociais e à necessidade de atuar sobre o interlocutor e, por isso, fatores de ordem não linguística devem ser observados na construção do texto conversacional. Corroborando essa perspectiva, a autora (2000, p. 71-72) aponta que:

[...] é fundamental que a atividade interacional esteja voltada para fatores sociais, como: idade, sexo, grau de conhecimento prévio, posição social, consideradas enquanto variáveis que determinam o grau de distanciamento entre os participantes da conversação. Conhecer as regras sociais implica saber agir de acordo com os padrões que regem a polidez e distinguir quando ela está sendo utilizada ou não.

Desse modo, a comunicação verbal consiste numa atividade intencional direcionada a um objetivo e pautada no uso adequado da linguagem, cabendo ao locutor avaliar a adequação de seu enunciado ao seu objetivo, sua categoria e seu interlocutor, com base em regras sociais que regem a preservação da imagem. Nesta pesquisa, Bolsonaro faz escolhas de estratégias e recursos conversacionais carregados de uma certa força ilocucionária intencional e diretamente relacionados à posição social que ocupa, o que, no entanto, não implica a adequação direta às regras sociais vigentes, uma vez que a opção pelo corpus de pesquisa adotado diz respeito à atuação contrária do presidente às orientações de órgãos de saúde nacionais e internacionais.

Ainda sobre as relações de simetria e assimetria em processos interacionais, é importante retomar a questão do turno conversacional e suas tipologias - nuclear e inserido. Galembeck (1997, p. 60) define o turno como um tempo fixo ou não associado a "várias situações em que os membros de um grupo se alternam ou se sucedem na consecução de um objetivo comum ou numa disputa: jogo de xadrez, corrida de revezamento, mesa-redonda”. No caso da conversação, há um revezamento de papéis entre falantes e ouvintes, composto por uma série de turnos intervindo entre os interlocutores.

Quanto às tipologias, o autor afirma que num turno nuclear, o falante desenvolve o tópico discursivo por meio da veiculação de informações, havendo um valor referencial em atos de fala que compõem seu turno. Os turnos inseridos, por sua vez, não necessariamente desenvolvem o tópico discursivo e têm a função de monitorar, fiscalizar ou acompanhar as palavras do locutor (GALEMBECK, 1997).

Nesse sentido, o papel do falante analisado neste estudo é direcionado por turnos inseridos pelo seu interlocutor, sobretudo na qualidade de repórter, que conduz o tópico discursivo e opera numa relação de assimetria, em que o presidente profere os turnos 
nucleares. No entanto, no caso de coletivas e pronunciamentos à imprensa, com alguns de seus interlocutores compostos por apoiadores, expectadores de rádios ou programas de televisão, internautas e governantes - como será observado mais adiante no Quadro 2, na contextualização dos trechos analisados - a relação de assimetria é ainda mais evidente, pois o par conversacional é composto por locutor e audiência, a qual não emite turnos inseridos ou nucleares.

Partindo desses pressupostos, na análise das falas do presidente brasileiro aqui proposta, serão considerados os turnos nucleares emitidos pelo político enquanto falante e relacionados ao tópico discursivo da pandemia do coronavírus no país. Portanto, haverá enfoque no par entrevistado-audiência levantado por Fávero (2000), no que concerne aos seus papéis sociais e à necessidade de atuação do falante sobre o interlocutor mediante ao tópico.

A seguir, apresentamos as falas contextualizadas de Jair Bolsonaro e tecemos análises com relação aos recursos por ele empregados.

\section{ANÁLISE DE FALAS DO PRESIDENTE JAIR BOLSONARO ACERCA DO INÍCIO DA PANDEMIA}

Partindo dos pressupostos da AC mencionados ao longo das sessões anteriores - a preservação de face por meio de estratégias de polidez, os marcadores conversacionais e as relações entre os pares conversacionais - a análise proposta neste trabalho trata de falas do presidente Jair Bolsonaro divulgadas pela mídia na fase inicial da pandemia de covid-19 no Brasil entre os meses de março e abril de 2020

O presidente foi entrevistado semanalmente por diversos repórteres, os quais tiveram como tópico discursivo principal, ao longo de 2020, a pandemia. Desde as medidas iniciais de prevenção tomadas pelas autoridades de saúde mundiais e nacionais em janeiro de 2020, o presidente adotou uma postura minimizadora da gravidade da doença e demonstrou atitudes e comportamentos contrários a essas orientações. Dessa maneira, envolveu-se em discursos polêmicos proferidos em entrevistas, coletivas, pronunciamentos e lives, nas quais, não somente por meio de escolhas linguísticas, mas de atitudes desconsiderando a proteção contra o vírus, como aglomeração de pessoas, apertos de mão, não uso ou uso inadequado de máscara de proteção, foram recursos por ele adotados para demonstrar incredulidade em relação ao problema vigente.

Visando a apresentar uma breve análise de suas escolhas linguísticas em relação ao tópico discursivo exposto com base nos conceitos da AC apresentados, são analisadas nove frases selecionadas e publicadas em 1 de maio de 2020 pelo website UOL Notícias na seção de saúde, proferidas por Bolsonaro entre o período de 9 de março a 28 de abril. Tal compilação foi utilizada como referência neste estudo, justamente por conter um histórico de manifestações do presidente mediante o tópico discursivo em evidência mundial, que repercutiram nacionalmente e culminaram em reações de desaprovação por parte de sua audiência, devido ao teor despreocupado, banalizador e até mesmo pejorativo com relação à situação.

Cabe ressaltar que no período em que as falas foram proferidas, o país ainda contava com pouco mais de 5 mil mortes pelo vírus e tal problema não foi colocado em primeiro plano pelo governo. À época, Bolsonaro enfrentava o envolvimento de seus filhos, também políticos, em esquema de divulgação de ataques e fake news na internet, além da crise econômica que se instaurava como consequência do distanciamento social e a paralisação das atividades comerciais.

Naquele momento de enfrentamento inicial, pouco se conhecia sobre a dimensão do problema, mas já se evidenciava seu alastramento em países europeus e as consequências de ordem econômica e sanitária já eram previstas, sendo os órgãos de saúde os principais atuantes nas orientações de combate à pandemia. Tendo isso em vista, o presidente demonstrou em suas falas a incredulidade na dimensão da pandemia e a persistência em negá-la como um problema a ser priorizado por medidas governamentais.

Com base nas informações fornecidas na publicação, o Quadro 2 foi organizado em ordem cronológica, conforme apresentado no website de origem, e traz, além dos trechos, uma breve explanação do momento em que foram emitidos. 
Quadro 2: Comentários do presidente Jair Bolsonaro sobre a pandemia entre os meses de março e abril de 2020

Data

$09 / 03 / 20$

$15 / 03 / 20$

$17 / 03 / 20$

$20 / 03 / 20$

$27 / 03 / 20$

$29 / 03 / 20$

$12 / 04 / 20$

$20 / 04 / 20$

$28 / 04 / 20$

\section{Fala do presidente}

Tem a questão do coronavírus também que, no meu entender, está superdimensionado, o poder destruidor desse vírus. Então talvez esteja sendo potencializado até por questão econômica, mas acredito que o Brasil, não é que vai dar certo, já deu certo.

Não podemos entrar em uma neurose como se fosse o fim do mundo. Outros vírus mais perigosos aconteceram no passado e não tivemos essa crise toda. Com toda certeza há um interesse econômico nisso tudo para que se chegue a essa histeria

Esse vírus trouxe uma certa histeria. Tem alguns governadores, no meu entender, posso até estar errado, que estão tomando medidas que vão prejudicar e muito a nossa economia.

Depois da facada, não vai ser gripezinha que vai me derrubar, não, tá ok? Se o médico ou o Ministério da Saúde recomendar um novo exame, eu farei. Caso contrário, me comportarei como qualquer um de vocês aqui presentes.

Se for todo mundo com coronavírus, é sinal de que tem estado que está fraudando a causa mortis daquelas pessoas, querendo fazer um uso político de números. [...] Em São Paulo não estou acreditando nesses números.

Essa é uma realidade, o vírus tá aí. Vamos ter que enfrentá-lo, mas enfrentar como homem, porra, não como um moleque. Vamos enfrentar o vírus com a realidade. É a vida. Todos nós iremos morrer um dia

Parece que está começando a ir embora essa questão do vírus, mas está chegando e batendo forte a questão do desemprego.

Ô, ô, ô, cara. Quem fala de... eu não sou coveiro, tá?

E daí? Lamento. Quer que eu faça o quê? Eu sou Messias, mas não faço milagre.

\section{Contexto}

Pronunciamento em evento com a comunidade brasileira em Miami, num momento em que registravam mundialmente 3.000 pelo coronavírus.

Em entrevista à CNN Brasil, após participar de atos pró-governo e com vários membros de sua comissão contaminados.

Em entrevista à rádio Super Tupi, prestes a completar 65 anos e a celebrar em uma "festinha tradicional".

Após entrevista coletiva ao lado do exministro da saúde Luiz Henrique Mandetta.

Em entrevista na TV Bandeirantes, duvidando do número de mortes e em meio à subnotificação de dados sobre a doença.

Em coletiva após passeio por Brasília ao lado de apoiadores, contrariando as orientações do Ministério da Saúde e da Organização Mundial de Saúde.

Em live com lideranças religiosas, após o país atingir mil mortos pela doença.

Em coletiva, interrompendo um jornalista em frente ao Palácio do Planalto, o qual se referia ao número de mortos pelo coronavírus.

Em entrevista coletiva, após 5 mil mortes registradas no país.

Fonte: Tajra $(2020)$

Nas falas compiladas pelo referido website, é possível perceber em suas contextualizações, que estas aconteceram predominantemente em entrevistas concedidas a jornalistas, transmitidas por redes de televisão e rádio: CNN (15/03/2020), Rádio Super Tupi (15/03/2020) e TV Bandeirantes (15/03/2020), ou de maneira coletiva, na qual o presidente se dispõe publicamente aos questionamentos de repórteres representando seus veículos de imprensa, como nos dias 20/03/2020, 29/03/2020, 20/04/2020 e 28/04/2020. Ainda, no dia 09/03/2020, o trecho em análise foi retirado de um pronunciamento do político em um evento internacional e no dia 12/04/2020, de uma live transmitida online. 
É importante ressaltar que, no caso das entrevistas coletivas ou não, ambas são guiadas por repórteres, sendo a presença do entrevistador demarcada por turnos inerentes, os quais possuem a função de conduzir o tópico discursivo central deste estudo. Já nos pronunciamentos e live, também utilizados neste corpus, os turnos inerentes são praticamente ausentes, uma vez que estes gêneros são conduzidos pelo próprio falante e não se estabelecem pelo revezamento de turnos do par entrevistador-entrevistado. Desse modo, os turnos inerentes não compuseram esta análise, sendo considerados os turnos nucleares do presidente, ou seja, falas de valor referencial acerca do tópico discursivo da pandemia do coronavírus no contexto nacional em eventos interacionais da esfera jornalística (GALEMBECK, 1997).

Assim, ao observar o par interacional entrevistado-audiência e a relação de assimetria que se estabelece nos eventos interacionais onde ocorreram as falas (FÁVERO, 2000), observamos adiante o papel social do falante e sua necessidade de preservação da imagem pública, por meio de estratégias conversacionais. Em um primeiro momento, no que tange à questão da face, é possível observar a preservação da face positiva do presidente, utilizada para reforçar sua imagem pública, sobretudo entre seus apoiadores, que concordam com sua descrença em evidências científicas acerca do tópico discursivo, tanto com relação à seriedade da pandemia, quanto aos dados consolidados a partir de seus efeitos no país. Visando à aceitação pública de seus argumentos, o presidente mantém, ao longo dos dois meses analisados, uma postura constante, a qual é ameaçada pelos fatos apresentados pelos órgãos responsáveis.

Por esse viés, em dois momentos distintos, o presidente ameaça a face negativa de seu ouvinte, ao proferir questionamentos ou refutações em seu turno de fala, como é o caso de “Depois da facada, não vai ser gripezinha que vai me derrubar, não, tá ok?”, em 20 de março e em “Ô, ô, ô, cara. Quem fala de... eu não sou coveiro, tá? ”, em 24 do mesmo mês. Com o uso da expressão de confirmação 'tá' ou de seu bordão 'tá ok' de modo interrogativo, Bolsonaro tende a discordar do que foi proferido no turno de seu entrevistador, não respondendo, de fato, ao questionamento proposto. Dessa maneira, conforme afirmado por KerbratOrecchioni (2006), o político escapa da imposição de seu interlocutor e, ainda, evita uma participação mais direta por meio de turnos nucleares sobre o tópico discursivo em foco.

Quanto à estratégia de polidez, na fala do dia 20 de março, Bolsonaro demonstra sua polidez positiva em "Caso contrário, me comportarei como qualquer um de vocês aqui presentes", ao se colocar como um de seus ouvintes e promover uma aproximação a estes falantes, enquanto alguém que, mesmo no cargo de presidente do país, também está sujeito ao vírus (GUIMARÃES, 2010).

Apesar desse caso de proximidade com seu expectador, os MCs presentes em outros trechos também indicam estratégias de distanciamento do falante com seu público e rejeição aos fatos relacionados à pandemia. No dia 17 de março, ao afirmar que a ação dos governadores afeta negativamente a economia brasileira, o presidente emprega um MC de rejeição que neutraliza sua crítica ao dizer "posso até estar errado", buscando flexibilizar sua colocação perante seus ouvintes governadores, que possivelmente discordariam desse pronunciamento.

No dia 12 de abril, ao contrastar a pandemia com outro problema nacional de diferente ordem - o desemprego - Bolsonaro afirma que a preocupação com o vírus está cedendo espaço para esta outra questão e, embora utilize a impessoalidade no emprego do MC de distanciamento "parece que", não apresenta, em seu turno de fala, respaldos para tal perspectiva de recuo do vírus.

Nesses casos em que os MCs evidenciaram o distanciamento do presidente de seus interlocutores, as falas aconteceram, respectivamente, em entrevista conduzida por um repórter de rádio e em uma live. É possível constatar que, independentemente de um impacto direto de turnos conversacionais estabelecidos pela presença de um interlocutor - no caso, o repórter - ou ao proferir falas sobre o mesmo tópico discursivo em live, na qual a audiência não estabelece turnos inerentes, o político emprega expressões linguísticas neutralizadoras de sua responsabilidade enquanto falante e a posição social que ocupa.

No que concerne aos MCs que marcam maior envolvimento do falante, é possível observar marcadores de opinião e hedges nas falas do presidente. Com relação ao primeiro tipo de MC, Bolsonaro marca a sua opinião em expressões utilizadas nos dias $09,17 \mathrm{e}$ 27 de março, em "acredito", "no meu entender" e "não estou acreditando", respectivamente. Nos dois primeiros casos, o presidente demonstra sua crença numa suposta superdimensão do problema e reprova a atitude dos governadores mediante ao avanço da 
pandemia. Embora no último trecho expresse descrença às estatísticas do número de mortes no estado de São Paulo, em todos os casos, o presidente expressa sua opinião em concomitância a evidências já constatadas por órgãos de saúde e instituições de pesquisa científica sobre a realidade da pandemia em andamento. Esses MCs são empregados pelo falante com o intuito de expor sua opinião e preservar sua autoimagem pública entre seus ouvintes. De acordo com Burgo, Storto e Galembeck (2013, p. 307), MCs construídos com verbos de valor cognitivo ou de percepção (acho que, creio que, percebo que e assemelhados) "reafirmam a presença e voz do falante, trazem-no para a situação discursiva, apresentando sua opinião".

Já no dia 15 de março, o tópico relacionado à supervalorização da pandemia aparece na fala do presidente e é referido como "neurose" e "histeria", sendo comparado a vírus anteriores mais perigosos. Nessa fala, Bolsonaro afirma, enfatizando sua opinião pelo marcador de opinião "com toda certeza", que a importância dada à pandemia é um indício de interesse econômico.

Nas quatro falas em que os MCs de opinião aparecem, vinculadas a um pronunciamento e entrevistas, é evidente, de modo geral, que a opinião de Bolsonaro vai contra instâncias que veiculam informações acerca do mesmo tópico discursivo, ou seja, os órgãos de saúde e as instituições de pesquisa científica. Nesse caso, o valor referencial de especialistas no assunto, cujo papel social é de informar a população nacional sobre o tópico discursivo, acaba sendo contraposto por falas compostas de opiniões próprias e que não representam devidamente o papel do político em vista de seu cargo.

Há, ainda, o emprego do MC hedge "talvez" no trecho "Então talvez esteja sendo potencializado até por questão econômica". Na visão de Rosa,os hedges: "Encontram-se semeados no discurso, muitas vezes em posição parentética, e abrangem diferentes formas estereotipadas. São advérbios, locuções adverbiais, expressões verbais, pequenas frases, etc., que introduzem um grau de incerteza ou de imprecisão nos enunciados em que ocorrem" (ROSA, 1992, p. 49).

Galembeck (1999, p. 187) assevera que os hedges que expressam incerteza são expressões do tipo "talvez, quem sabe, sei lá, não sei” e similares, as quais "diminuem a força ilocutória dos enunciados opinativos e, assim, fazem com que o locutor não se veja tão comprometido com os juízos emitidos". Igualmente aos hedges que indicam planejamento verbal, os hedges que denotam “incerteza ou imprecisão ocupam uma posição parentética nos enunciados”.

Observamos, então, no trecho do dia 09 de março, a estratégia de distanciamento do presidente enquanto locutor e sua opinião marcada por meio de verbo em primeira pessoa em "Tem a questão do coronavírus também que, no meu entender, está superdimensionado, o poder destruidor desse vírus". Em seguida, o presidente muda de estratégia e passa a se envolver no tópico, conforme assinalamos no trecho "Então talvez esteja sendo potencializado até por questão econômica, mas acredito que o Brasil, não é que vai dar certo, já deu certo”, em que o MC talvez demonstra incerteza e parcializa um discurso minimizador da pandemia, no intuito de flexibilizar medidas preventivas para a continuidade das atividades econômicas e retomar a questão da supervalorização do problema. Trata-se de um hedge da força ilocutória, pois, de acordo com Rosa (1992, p. 39), "[...] os hedges da força ilocutória abrangem vários verbos e advérbios que diluem ou tornam ambígua a força ilocutória do enunciado, como, por exemplo, os advérbios realmente, certamente e talvez".

Além dos MCs observados, outros recursos linguísticos utilizados por Bolsonaro remetem ao polo polêmico na relação entre o par entrevistado-audiência típico de entrevistas jornalísticas, levantado por Fávero (2000). Reforçando postura minimizadora da pandemia, o presidente emprega frases de conhecimento comum nos dias 15: "como se fosse o fim do mundo", e 29 de março: "todos nós vamos morrer um dia". Nos dois momentos, a fala do presidente reforça aspectos por ele defendidos em torno do tópico discursivo em foco, abrandando, novamente, a gravidade representada pela propagação do coronavírus e menosprezando o crescente número de mortes.

Já na última fala apresentada pelo website, do dia 28 de abril, o presidente demonstra, por meio de um trocadilho com seu nome, indiferença pelos desdobramentos do tópico discursivo, ao abordar o número de mortes pelo coronavírus. Ao proferir "eu sou Messias, mas não faço milagre", Bolsonaro coloca sua imagem ao lado de valores cristãos e declara sua ausência de responsabilidade com a pandemia. Sobretudo nesse enunciado, é evidenciada a falta de preocupação por parte do político com regras sociais vinculadas à polidez, o que aponta para uma ação descompromissada com padrões que corroboram a sua imagem pública. 
Considerando-se que, desde sua campanha eleitoral ao cargo em 2018, o presidente já demonstrava não se envolver em questões de âmbito nacional, a exemplo dos debates eleitorais de segundo turno, nos quais não esteve presente, o político já utilizava estratégias de preservação da face como forma de se distanciar de questionamentos de seus interlocutores. Aliado a esses mecanismos, por meio de pronunciamentos acerca de tópicos discursivos variados desde o início de seu mandato presidencial, Bolsonaro lançou mão da polêmica como recurso retórico, não se apoiando em evidências científicas, mas se embasando em discursos de cunho conservador, religioso e reacionário (PIOVEZANI, 2019).

Assim, retomamos o fato de que a comunicação é uma atividade intencional, com um objetivo específico, a qual requer o uso adequado da linguagem e o conhecimento das regras sociais que regem a preservação da imagem. Mantendo sua imagem de "celebridade midiática" (PIOVEZANI, 2019, p. 386), Bolsonaro não agiu diferentemente em seus proferimentos acerca da pandemia, demonstrando por meio dos recursos de linguagem apontados em cada uma das nove falas analisadas neste estudo, seu teor autoritário e o predominante distanciamento do tema, deixando aos seus interlocutores a interpretação de seus atos e promovendo a banalização do mal, ao ignorar seu papel social diante da necessidade de atuação sobre o tópico conversacional eminente.

O conceito de banalização é abordado por vários outros estudos, a destacar o termo cunhado por Hannah Arrendt de "banalização do mal". Tendo vivenciado as atrocidades do nazismo, a estudiosa se referiu ao amparo no princípio de legalidade, a fim de se realizar atos que não garantem o bem do próximo, o que, no caso, pode ser interpretado por práticas nazistas desumanas (LIMA, 2020). Dessa maneira, a postura de Bolsonaro em relação ao coronavírus, com a negação constante do problema, bem como o distanciamento da responsabilidade pelo combate à pandemia, expressos em seu texto conversacional, possivelmente afetou o enfrentamento da doença por parte de seu público, os interlocutores nesta perspectiva analítica.

\section{CONSIDERAÇÕES FINAIS}

As falas apresentadas neste estudo aconteceram em meio a um momento de tensão mundial e tiveram como enfoque o posicionamento do presidente brasileiro Jair Bolsonaro acerca do tópico discursivo da pandemia do coronavírus. A partir da cronologia das falas ao longo dos meses de março e abril de 2020 compiladas em matéria publicada pelo site UOL, com o país registrando os primeiros efeitos da pandemia, o presidente demonstrou, nos textos analisados, uma postura despreocupada, descrente e minimizadora do problema.

Em aspectos levantados por meio da análise de estratégias e marcadores linguísticos pautada na AC, foi possível evidenciar que o político, mediante fatos confirmados por meio da ciência e da pesquisa, defendidos por especialistas na área da saúde e órgãos de dimensão nacional e mundial competentes, ainda assim, buscou enfrentar o problema por meio de estratégias de distanciamento, recursos de incerteza e retomada de frases e valores de outras instâncias, promovendo ao público, uma falsa noção de banalização do problema mundial eminente.

Vale ressaltar que as escolhas linguísticas adotadas ao proferir sua opinião contrária aos fatos, mantiveram sua autoimagem, sobretudo por meio de turnos nucleares de valor referencial sobre o problema. Nesse âmbito, evidenciou-se uma postura autoritária do político, uma vez que se manifestou sem a inserção de turnos inerentes, ou seja, sem a interação direta de seus interlocutores. Em algumas das falas, ainda, percebeu-se a ameaça de sua face positiva por meio do sarcasmo, crítica ou mesmo insulto de seu interlocutor ou de instâncias relacionadas aos fatos por ele refutados.

Por fim, é importante salientar que, de acordo com os resultados desta pesquisa, os procedimentos de preservação da face, de polidez, assim como os marcadores conversacionais empregados como formas de distanciamento e de envolvimento do falante com o tópico discursivo contribuíram para evidenciar sua postura de incredulidade acerca das estatísticas e orientações de órgãos de saúde nacionais e internacionais em relação ao enfrentamento da pandemia de COVID-19. 


\section{REFERÊNCIAS}

BROWN, P.; LEVINSON, S. C. Politeness: some universals in language usage. 2. ed. Cambridge: Cambridge University Press, 1987 [1978].

BROWN, G.; YULE, G.. Discourse Analysis. Cambridge: Cambridge University Press. 1983.

BURGO, V. H.; STORTO, L. J.; GALEMBECK, P. de T. O caráter multifuncional dos marcadores de opinião "Eu acho que” e "I think” na fala dos presidentes Lula e Obama.Domínios de Lingu@gem, v. 7, n. 2, p. 289-312, 2013.

FÁVERO, L. L. O tópico discursivo. In: PRETI, D. (org.). Análise de textos orais. 3. ed. São Paulo: Humanitas Publicações FFLCH/USP (Projetos Paralelos), 1997. p. 33-54.

FÁVERO, L. A representação da imagem pública nas entrevistas (SBPC 99). Linha D’Água, n. especial, p. 67-72, jan. 2000.

FÁVERO, L. L.; ANDRADE, M. L CVO; AQUINO, Z. G. O. Papéis discursivos e estratégias de polidez nas entrevistas de televisão. Veredas-Revista de Estudos Linguísticos, v. 4, n. 1, p. 67-77, 2000.

GALEMBECK, P. de T. O Turno conversacional. In: PRETI, D. (org.). Análise de textos orais. 2. ed. São Paulo: Humanitas Publicações FFLCH/USP (Projetos Paralelos), 1997. p. 55-79.

GALEMBECK, P. de T. Preservação da face e manifestação de opiniões: um caso de jogo duplo. In: PRETI, Dino. (org.) O discurso oral culto. 2. ed. São Paulo: Humanitas Publicações - FFLCH/USP (Projetos Paralelos), v. 2, 1999. p. 173-194.

GOOGLE NOTÍCIAS. Coronavírus. Disponível em: https://news.google.com/covid19/map?hl=pt-

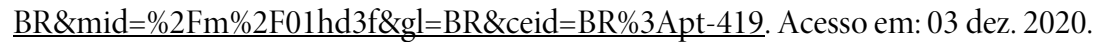

GUIMARÃES, S.. A construção de face e a (im)polidez linguística em entrevistas de Veja. Dissertação. Universidade Federal do Espírito Santo. 2010.

KERBRAT-ORECCHIONI, C. Análise da conversação: princípios e métodos. Trad. Carlos Piovezani Filho. São Paulo: Parábola, 2006.

LIMA, S. A.. Uma análise da pandemia de coronavírus sob o enfoque da banalização do mal de Hannah Arendt. Revista Brasileira de Filosofia do Direito, v. 6, n. 2, p. 22-37, 2020. Disponível em: https://indexlaw.org/index.php/filosofiadireito/article/view/7108. Acesso em: 21 out. 2021.

LINS, M. da P. P.; MARCHEZI, N. M. Estratégias de Proteção de Face: uma análise de entrevistas do programa CQC. In: CONGRESSO NACIONAL DE LINGUÍSTICA E FILOLOGIA, 16., 2012, Rio de Janeiro. Anais... Rio de Janeiro: Universidade do Estado do Rio de Janeiro, 2012. p. 553-561.

MARCUSCHI, L. A. Análise da conversação. Ed. Ática, 1991.

PIOVEZANI, C. A retórica do mito: Uma análise do desempenho oratório de Bolsonaro na propaganda eleitoral. Discurso \& Sociedad, n. 3, p. 383-410, 2019. Disponível em: http://www.dissoc.org/ediciones/v13n03/DS13\%283\%29Piovezani.pdf. Acesso em: 21 out. 2021 . 
RODRIGUES, Â. C. S.. Língua falada e língua escrita. In: PRETI, D. (org.). Análise de textos orais. 3. ed. São Paulo: Humanitas Publicações FFLCH/USP (Projetos Paralelos), 1997. p. 13-32.

ROSA, M.de M. Marcadores de atenuação. São Paulo: Contexto, 1992.

SILVA, S. F. Debate de opinião: perspectiva discursiva em um contexto de ensino-aprendizagem do francês como a língua estrangeira. Revista Intercâmbio, São Paulo, v. 24, p. 65-90, 2011.

TAJRA, A. Todos nós vamos morrer um dia: veja falas de Bolsonaro sobre o coronavírus. UOL, $1^{\circ}$ maio 2020. Disponível em: https://noticias.uol.com.br/saude/ultimas-noticias/redacao/2020/05/01/todos-nos-vamos-morrer-um-dia-as-frases-debolsonaro-durante-a-pandemia.htm. Acesso em: 27 nov. 2020.

\section{(1) $\circledast$}

